ACTA VET. BRNO, 47, 1978: $91-95$

\title{
ACTIVITY OF CREATINE-PHOSPHOKINASE IN THE COURSE OF EXPERIMENTAL TRICHINELLOSIS
}

\author{
H. SCHANZEL, E. HEGEROVÁ, B. KOUDELA, V. LOHR
}

Department of Pathological Morphology and Parasitology, Department of Pharmacology and Toxicology, University of Veterinary Science, 61242 Brno

Received February 21, 1978

\begin{abstract}
Schanzel H., E. Hegerová, B. Koudela, V. Lohr: Activity of Creatine-Phosphokinase in the Course of Experimental Trichinellosis. Acta vet. Brno, 47, 1978: $91-95$.

Activity of serum creatine-phosphokinase has been determined at different intervais after experimental infestation of mice and guinea pigs by larvae of Trichinella spiralis. Blood samples were treated by Bio-La-test kreatinkináza Lachema, measurements were performed on the spectrophotometer UV VIS at $400 \mathrm{~nm}$ wavelength. Intensity of parasitic infestation was estimated by the number of larvae in $1 \mathrm{~g}$ of muscle tissue.

No significant difference from control values was found in infested animals at any stage of trichinellosis. Determination of CPK activity seems not to be convenient for intravital detection of trichinellosis.
\end{abstract}

Guinea pigs, mice, serum CPK, muscle.

Determination of activity of plasmatic creatine-phosphokinase developed to a favourite method for investigation of various myositic processes in man and animals. It not only became a routine method for diagnostics of heart attack - Pojer a. o. (1963), Gerber (1965), Ninger (1968), but, it has been studied in connection with muscular dystrophy and other neuromuscular disorders - Okineka and Kumagai (1961), Pearce a. o. (1964), Hatnarska a. o. (1968), with degenerative myopathy in young cattle - Gils and Zayed (1966), Dotta and Robutti (1972), Martig a. o. (1972), McMurray and McEldowney (1977), with muscular dystrophy in pigs - Steinhauser and Rochová (1977), with tetanus - Irwin (1967), with hypothermia and stress - Meltzer (1971), with muscular affection due to intoxications and infections - Oldershausen a. o. (1965), with fatal intoxication by carbon monoxide - Bour a. o. (1962), with extraordinary physical exhaustion and hypoxia - Cunningham and Critz (1972).

Considering the role of creatine-phosphokinase in physiology and pathology of the muscle, we took it for justified to investigate whether changes in CPK activity would occur in consequence of migration and settlement of larvae of Trichinella spiralis. Prior to the trial, physiological values for CPK activity were to be determined in mice and guinea pigs, since the two species were intended to be used for infestation - Schanzel and Hegerová (1978). Numerous interactions between host and larva of T. spiralis have been known for long. According to Borchert (1954), the attacked muscle shows decrease in total nitrogen, creatine, purine bases, and increase in water, lactic acid, volatile fatty acids, ammonia and products of muscle decay. An enzymatic response by increased phosphatase activity has been demonstrated by Schanzel and Holman (1966).

\section{Material and Methods}

A total of 160 mice and 19 guinea pigs were infested by viable larvae of Trichinella spiralis, obtained by digestion method from experimentally infested rats. Approximately 200 larvae were administered orally to each mouse and about 1000 larvae to each guinea pig. Successively, 10 in- 
fested mice were used for determination of serum CPK activity at days $2,3,4,5,6,8,10,11$, $12,14,21,28,35,41,49$ and 56 p. i. Simultaneously with each infested group, eight control mice were examined.

Blood samples were collected by exsanguination of mice. Samples from very small animals were pooled by $2-3$, to obtain the needed amount of serum. The samples were treated with Bio-La-test Lachema in the way described by the producer, but, the amounts of components had to be doubled in order to obtain a volume sufficient to fill the measuring cell. Determinations of CPK activity were performed on the spectrophotometer UV VIS at $400 \mathrm{~nm}$ wavelength, with automatical recording of extinction.

Blood samples from guinea pigs were collected by heart puncture, immediately centrifuged and processed in the same way as samples from mice. The punctures were repeated twice or three times in each guinea pig, first at day 42, and than at day 156 and 197 p.i.

Following determination of CPK activity, the experimental animals were killed. Samples of $1 \mathrm{~g}$ muscle tissue - $\mathrm{mm}$. masseteri from guinea pigs and $\mathrm{mm}$. quadricipies and $\mathrm{mm}$. longissimi dorsi from mice - were microscopically examined for the number of larvae of $T$. spiralis.

Limits of confidence were calculated for statistical evaluation of results.

\section{Results}

The activity of serum creatine-phosphokinase in control mice and at different intervals p. i. with $T$. spiralis is illustrated in Figure 1.

In Table 1 , the levels of $\mathrm{CPK}$ activity and the number of larvae/g muscle tissue are compared.

Table 2 demonstrates the same correlation in individual mice, examined 6 weeks p. i.

Proportion between CPK activity in guinea pigs, examined repeatedly at different intervals p. i., and number of larvae/g of their muscle tissue are summarized in Table 3.

\section{Discussion}

Mean values of CPK activity determined at different intervals p. i. of mice seem to indicate a certain correlation with the life history of Trichinella spiralis. The maximum at days 5 and 10 might corresponds to intestinal and migrational

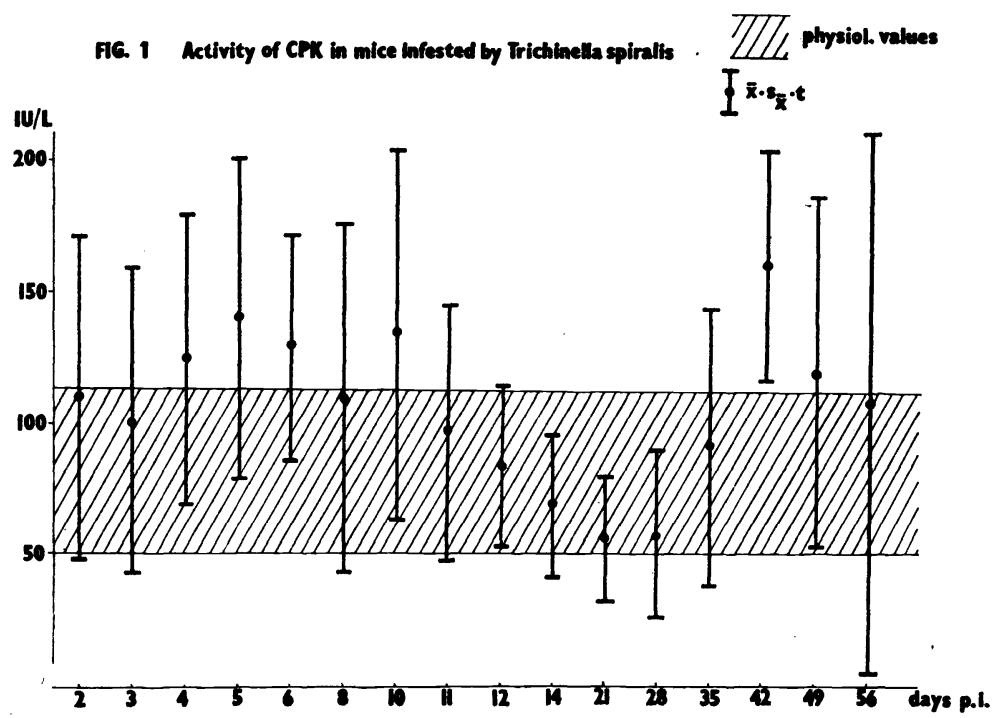


stages of trichinellosis. Nevertheless, the limits of confidence demonstrated in Fig. 1 make it obvious that no such interpretation can be justified. Only the 10 animals examined 42 days $\mathrm{p}$. i. formed a group differring from values in normal mice just on the border of significance $(P=0.05)$. The CPK activity in blood serum of infested mice was $160.98 \pm 41.29$, while the value in control mice was $82.67 \pm 31.13 \mathrm{IU} / \mathrm{L}$.

Not even in this group there was a correlation between CPK activity and intensity of infestation by larvae of $T$. spiralis. Table 1 shows CPK activity and number of larvae/g muscle tissue group by group, Table 2 the same values separately for each animal in the group examined 42 days $p$. i. It is obvious from both tables than neither a direct nor an indirect correlation could be established between CPK activity and the number of parasitic larvae.

The results with infested guinea pigs are summarized in Table 3. Here again is to be seen that there is no significant difference between CPK activity in infested and control animals, and, that there is no correlation between CPK activity and intensity of infestation in the course of trichinellosis.

The conclusion resulting from our trial is that the expected effect of larvae of Trichinella spiralis on the activity of creatine-phosphokinase in blood serum of the host could not be observed. Infestation by a larger number of larvae would

Table 1

Serum CPK activity in mice and number of $T$. spiralis larvae/g muscle tissue

\begin{tabular}{|c|c|c|}
\hline $\begin{array}{l}\text { Day } \\
\text { p. i. }\end{array}$ & $\begin{array}{c}\text { CPK activity IU/L } \\
\bar{x} \pm s_{\bar{x}} \cdot t\end{array}$ & $\begin{array}{c}\text { No. of larvae/g muscle } \\
\bar{x} \pm s_{\bar{x}} \cdot t\end{array}$ \\
\hline 2 & $105.48 \pm 60.11$ & - \\
3 & $97.23 \pm 58.60$ & - \\
4 & $115.60 \pm 54.98$ & - \\
5 & $138.14 \pm 59.02$ & - \\
6 & $127.67 \pm 40.66$ & - \\
8 & $109.90 \pm 67.44$ & - \\
10 & $132.78 \pm 72.82$ & $422 \pm 195$ \\
11 & $94.62 \pm 47.75$ & $306 \pm 110$ \\
12 & $72.17 \pm 29.41$ & $394 \pm$ \\
14 & $61.24 \pm 26.87$ & $313 \pm 143$ \\
21 & $50.83 \pm 24.93$ & $291 \pm 103$ \\
28 & $55.33 \pm 33.76$ & $415 \pm 201$ \\
35 & $94.75 \pm 51.14$ & \\
42 & $160.98 \pm 41.29$ & \\
49 & $113.42 \pm 69.33$ & \\
56 & $104.54 \pm 104.20$ & \\
\hline
\end{tabular}

Table 2

Correlation between CPK activity and number of T. spiralis larvae/g muscle tissue in mice 6 weeks p. i.

\begin{tabular}{|c|c|c|}
\hline $\begin{array}{c}\text { Mous } \\
\text { No. }\end{array}$ & CPK activity IU/L & No. of larvae/g muscle tissue \\
\hline & & \\
121 & 175.75 & 715 \\
122 & 205.97 & 88 \\
123 & 234.05 & 176 \\
124 & 126.52 & 154 \\
125 & 133.67 & 72 \\
126 & 99.22 & 162 \\
127 & 102.10 & 129 \\
128 & 86.86 & 1482 \\
129 & 178.98 & 57 \\
130 & 255.70 & 95 \\
\hline
\end{tabular}


Table 3

CPK activity and number of $T$. spiralis larvae in guinea pigs at different age

\begin{tabular}{|c|c|c|c|c|c|}
\hline Group & $\begin{array}{c}\text { No. of } \\
\text { animals }\end{array}$ & Age days & Days p. i. & CPK activity IU/L & No. of larvae/g muscle \\
\hline Infested & $\begin{array}{r}19 \\
10 \\
5\end{array}$ & $\begin{array}{r}42 \\
156 \\
197\end{array}$ & $\begin{array}{r}9 \\
147 \\
188\end{array}$ & $\begin{array}{l}46.24 \pm 8.21 \\
42.68 \pm 9.88 \\
41.35 \pm 13.02\end{array}$ & $\begin{array}{l}2280 \pm 543 \\
1487 \pm 602 \\
1624 \pm 721\end{array}$ \\
\hline Control & $\begin{array}{l}12 \\
12 \\
12\end{array}$ & $\begin{array}{r}42 \\
156 \\
197\end{array}$ & $\begin{array}{l}- \\
-\end{array}$ & $\begin{array}{l}38.36 \pm 7.22 \\
40.71 \pm 6.84 \\
40.65 \pm 6.58\end{array}$ & $\begin{array}{l}- \\
-\end{array}$ \\
\hline
\end{tabular}

hardly result in a significantly elevated CPK-activity. Determination of CPK activity is thus not a convenient subsidiary method for detecting trichinellosis intravitally.

\section{Aktivita kreatinfosfokinázy $\mathrm{v}$ průběhu experimentální trichinelózy}

U myší a morčat, experimentálně invadovaných larvami Trichinella spiralis, jsme $\mathrm{v}$ různých intervalech po invazi stanovovali aktivitu sérové kreatinfosfokinázy. Vzorky se zpracovaly Bio-La-testem Lachema, jejich aktivita se měřila na spektrofotometru Specord UV VIS při $400 \mathrm{~nm}$ vlnové délky, s automatickou registrací extinkce. Intenzita invaze se posuzovala podle počtu larev $T$. spiralis na $1 \mathrm{~g}$ svaloviny. Pro statistické vyhodnocení výsledků se vypočítaly meze spolehlivosti.

Výsledky ukázaly, že se aktivita kreatinfosfokinázy v průběhu experimentální invaze $T$. spiralis signifikantně nemění a že mezi aktivitou enzymu a intenzitou invaze není žádná korelace. Stanovení aktivity kreatinfosfokinázy není vhodné pro intravitální diagnostiku trichinelózy.

Активность креатинфосфокиназы в течение экспериментального трихинеллеза

У мышей и морских свинок, экспериментально зараженных личинками Trichinella spiralis, устанавливали активность сывороточной креатинфосфокиназы в различные промежутки времени после инвазии. Образцы обрабатывали с помощью Био-Латеста Лахема, их активность измеряли на спектрофотометре Specord UV VIS при $400 \mathrm{~nm}$ длины волны, с автоматической записью экстинции. Интенсивность инвазии оценивалась по количеству личинок T. spiralis на 1 г мышечной ткани. В целях статистической оценки рєзультатов исчисляли предельные величины надежности.

Результаты показали, что активность креатинфосфокиназы в течение әкспериментальной инвазии $T$. spiralis существенно не изменяется и что между активностью энзыма и интенсивностью инвазии не существует никакой корреляции. Определение активности креатинфосфокиназы не является удобным для прижизненной диагностики трихинеллеза. 


\section{References}

BOUR, H. - DUROUX, P. - GLIMET, T. - GLOUVEL, M.: Les enzymes du muscle au cours du coma oxycarboné. Sem. Hop. 38, 1962, 3152-3157.

BORCHERT, A.: Lehrbuch der Parasitologie für Tierärzte. S. Hirzel, Leipzig 1954.

CUNNINGHAM, D. A. - CRITZ, J. B.: Hypoxia and enzymes. Int. Zschr. angew. Physiol, 30, 1972, 302-308.

DOTTA, U. - ROBUTTI, B.: Studio dei livelli della transaminasi glutaminico-assalacetico e glutamino-piruvico, della aldolasi e della creatin-fosfochinasi, in vitalli normali e in vitalli affetti da miodistrofia enzootica. Folia vet. latina 2, II., 1972, 310-325.

GERBER, H.: Aktivitätsbestimmungen von Serumenzymen in der Veterinärmedizin. Schweiz. Arch. Thkd. 107, 1965, 685-697.

GILS, J. H. J. van - ZAYED, I.: Myodegeneration in Friesian Beef Calves. Tijdschr. Diergeneesekd. 91, 1966, 1375-1421.

HATNARSKA, L. - PROT, J. - SAVICKA, E.: CPK activity in spinal muscular atrophy. J. Neurol. Sci. 6, 1968, $261-267$.

IRWIN, A.: Origin of increased serum CPK in tetanus. Arch. Neur. 16, 1967, 89-93.

MARTIG, J. - GERBER, H. - GERMAN, F. - HAUSWIRTH, H. K. - TONTIS, A.: Untersuchungen zum Zitterkrampf des Kalbes, einer Verlaufsform der Weissmuskelkrankheit. Schweiz. Arch. Thkd. 114, 1972, 266-275.

MELTZER, H. Y.: Plasma creatine phosphokinase activity, hypothermia and stress. Am. J. Physiol. 221, 1971, 896-901.

MCMURRAY, C. H. - McELDOWNEY, P. K.: A possible prophylaxis and model for nutritional degenerative myopathy in young cyttle. Brit. Vet. J. 133, 1977, 535-542.

NINGER, E.: Enzymová diagnostika srdečního infarktu. Cas. lék. čs. 107, 1968, 1168-1171.

OLDERSHAUSEN, H. F. von - LÚTJE, A. - EGGSTEIN M. - ZYSNO, E.: Zur Serumdiagnostik von Muskelaffektionen bei Intoxikationen und Infektionskrankheiten. Verh. dt. Ges. inn. Med. 71, 1965, 653-659.

OKINEKA, S. - KUMAGI, M.: Activity in progressive muscular dystrophy and neuromuscular diseases. Arch. Neurol. 4, 1961, 520-526.

PEARCE, M. J. - PENNINGTON, R. J. - WALTON, J. N.: Serum CPK activity in muscular dystrophy and in other myopatic and neuropatic disorders. J. Neurol. Neurosurg. Psychiatr. 27, 1964, 96-99.

POJER, J.: Enzymologie srdečního infarktu. SZdN Praha, 1963.

SCHANZEL, H. - HEGEROVÁ, E.: Activity of creatine phosphokinase in mice and guinea pigs. Acta vet. Brno.

SCHAZEL, H. - HOLMAN, J.: Lokalisation der alkalischen Phosphatase in der trichinellabefallenen Muskulatur. Angew. Parasitol. 7, 5, 1966, 252-259.

STEINHAUSER, J. - ROCHOVÁ, I.: Aktivita kreatinkinázy při svalové dystrofii prasat. Stud. věd. konference VŠV Brno, 1977. 